\title{
Focus in Bantu: verbal morphology and function*
}

\author{
Derek Nurse \\ Memorial University of Newfoundland
}

\begin{abstract}
Although verb forms encoding focus were recorded in various Bantu languages during the twentieth century it was not until the late 1970's that they became the centre of serious attention, starting with the work of Hyman and Watters. In the last decade this attention has grown. While focus can be expressed variously, this paper concentrates largely on its morphological, partly on its tonal expression. On the basis of morphological and tonal behaviour, it identifies four blocks of languages, representing less than a third of all Bantu languages: those with metatony, those with a binary constituent contrast between verb ("disjunctive") and post-verbal ("conjunctive") focus, those with a three-way contrast, and those with verb initial /ni-/. Following Güldemann's lead, it is shown there is a fairly widespread grammaticalisation path whereby focus markers may come to encode progressive aspect, then present tense. Many Bantu languages today have a prestem morpheme /a/ 'non-past' and it is hypothesized that many of these /a/, which are otherwise hard to explain historically, may derive from an older focus marker.
\end{abstract}

\section{Introduction}

By contrast with other studies which have concentrated on focus in particular Bantu languages or groups of languages, this is an overview of focus across Bantu. It offers no new data or theoretical insights but is at once an attempt to synthesise what others have done and to explore some of the possible historical antecedents of what occurs today. It concentrates on focus marking on the verb, that is, primarily on morphology and to some extent on tonal correlates. It does not deal with syntax, particles, or the noun augment, which all play a role in focus. It examines morphological features occurring in major blocks of languages and ignores those only found in a few languages.

I thank Christa Beaudoin-Lietz, Larry Hyman, Sarah Rose, Thilo Schadeberg, and ZAS's anonymous reviewer for comments on the first draft of this paper. 


\section{Definition(s)}

Concentrating on information, Watters (1979) defines focus as "that information in the sentence that the speaker believes, assumes or knows the hearer does not share with him or her". He and others recognize different discourse functions for focus, such as assertive and contrastive focus. More concerned with the scope of the focus in the utterance, Wald (1997: 57) says: "purpose of a constituent focus system is to assign the maximal focus of a clause to one or another clause constituent". In the same vein, Güldemann (2003) distinguishes three types of scope of focus: term, verb, and truth. Term focus refers to a non-verbal constituent, usually post-verbal ("I'm going to eat porridge"), verb focus refers to the lexical content of the verb ("I'm going to eat it, not drink it"), and truth focus concerns the grammatical categories attached to the verb (tense, aspect, modality: "I'm going to eat it"). Güldemann (2003: 329) acknowledges his intellectual debt to Dik (e.g. 1997), but I cite Güldemann here, since I am following him, rather than Dik (and other sources cited by Güldemann). In what follows I often use the terms post-verbal or clause-final focus (more or less equivalent to Güldemann's term focus) and verb focus (his verb and truth focus), because they occur commonly in the sources.

\section{How focus is expressed in Bantu}

Focus is indicated across Narrow and Grassfields Bantu by some combination of: word order/movement, clefting, particles, tone, reduplication of the verbal word, verb morphology, and object shape. Examples in (1) are from Aghem, a Grassfields language (Watters (1979)):

(1) a. fíl á mo zíkí-béán 'sóm

friends they past eat fufu in farm

'Friends ate fufu on the farm.'

b. fíl á mo zí án 'sóm bé-'kó

friends they past eat in farm fufu

'Friends ate fufu on the farm.'

c. kí mô dzòo nò

it was good FOC

'It was good.' 
d. $\quad$ kí mô dzòo nò né
'It was good today.'
e. kí máā dzò
it was.FOC good
'It was good/came out well.'

In $(1 \mathrm{a}, \mathrm{b})$ the immediately post-verbal constituent is focused (post-verbal focus, word order) and the noun has a different shape, depending whether it is in focus. (1c) focuses on 'good' by postposing the particle n', and (1e) focuses on the pastness of the verb (verb focus) by its having a different morphology from (1d).
a. Kongo $^{1}$ sumba tu-n-sumba
buy we-PROG-buy
'We are buying'
b. Swahili a-lia-lia tu
'It (child) does nothing but whimper'
c. Vunjo
ni kiki u-le-soma
is what you-past-read
'What did you read?'
$\begin{array}{ll}\text { d. Ganda } & \text { y-a-lába omukázi 'He saw a woman', but } \\ \text { y-a-lábá mákázi 'He saw a woman' }\end{array}$

Kongo and Swahili reduplicate the verb, Kongo also involves infinitive fronting (verb focus). The Vunjo example involves clefting. The Ganda example involves the presence/absence of the nominal preprefix and a tonal difference. Other tone contrasts can be seen in (3) and tone is taken up again in section 9. Thinking about focus in Bantu has been largely based on, and shaped by, its appearance in four groups of languages: Grassfields Bantu ${ }^{2}$ (exemplified in (1) and (15)); the Zone $\mathrm{S}$ languages of southern Africa (including K21) ${ }^{3}$, discussed in section 5, below; a set of Lacustrine (D60, E40) and Zambian (M40-50-60) languages, also discussed in section 5: a set of languages in Kenya and Tanzania (E40, E50, E60), dealt with in section 7. To these I have added languages with metatony (section 4, below) and other possibilities are mentioned in sections 6

1 Kongo example from De Clercq (1912), Vunjo from Dalgish (1976), Ganda from Hyman (p.c.). Here (e.g. Swahili) and elsewhere, where no source for examples is given, it is Nurse (in progress). Glosses are those given in the sources, or, where the examples are my own, I have supplied the gloss.

2 Grassfields Bantu, spoken in the Cameroon, is usually said to be different from Narrow Bantu but the differences are ill-defined.

3 Where languages are referred to by number, the latter are from Maho (2003). 
and 10. The languages in sections 5, 6, 7 and 10 - where the surface is only now being scratched - represent under a third of all Bantu, so more work is necessary in order to have an adequate picture of focus across Bantu.

\section{$4 \quad$ Metatony}

Many - exact number not known - Forest languages show a tonal process called metatony: Zones A, B, C, D10, D20. In metatony a verb final vowel(s) is underlyingly non- $\mathrm{H}$ when utterance final but $\mathrm{H}$ when followed by a complement (object, adverbial...in the same phrase?) and the $\mathrm{H}$ may carry over onto the first TBU of the complement. It tends to characterize some tenses/aspects of each language and not others. It is often described as just a tonal process, and is thus similar to high tone shift or spread, but it is striking that it has certain characteristics linking it to focus: it seems to affect certain (mostly positive) tenses in the language (e.g. Guarisma 2003: 320-327) and marks a contrast between verb focus and post-verbal focus. This suggests it is not merely a tonal process but has a syntactic-semantic function, an opinion shared by Schadeberg (1995: 176, also Dimmendaal 1995: 32, de Blois 1970: 107). Examples: ${ }^{5}$
a. Duala
wána
b.
a ma-wáná mabato
bitó bá-manda
bító bá-mandá mabato
c. Basaa
a bí nunul
a bí nuyúl bísel
nuyúl bisel

'(to) bring', but

'She brings clothes'

'Women buy', but

'Women buy clothes'

'He sold', but

'He sold baskets' (metatony), but

'Sell baskets' (verb but not noun affected)

d. Mituku kukúlúmanisa 'to assemble', but kukúlúmánísá bantu

At first sight, this looks as if what was originally a tonal process became used to encode a function, and that function looks like what follows in section 5: verb versus post-verbal focus. However, in all the cases below, it is the post-verbal focus form (conjunctive) that is unmarked or less marked, whereas here the conjunctive is apparently marked (by the $\mathrm{H}$ ). The nature and origin of this whole tonal phenomenon needs more examination, as does the issue of whether other types of focus and other strategies exist in the Forest languages.

4 Meeussen (1967: 111) thinks metatony can be reconstructed for Proto-Bantu but I am not convinced its current geographical distribution warrants that.

5 Basaa examples from Hyman (p.c.). 


\section{Tense marker plus focus, binary contrast: conjunctive versus disjunctive focus}

Certain Savanna languages contrast post-verbal and verb focus, the latter marked by an inflectional morpheme following the tense-marker: D60, M40, (M50), M60, P20-30, S20-30, K21, S40-50. This contrast is talked about in the literature in two slightly different ways: in terms of the relationship between verb and other constituents, or in terms of what is focused. Conjunctive (postverbal $^{6}$ ) forms are said to emphasize the close relationship between the verb and a following constituent, such as object, adverbial, wh-word, or prepositional phrase in the same clause. Disjunctive (verb focus) forms indicate there is no special relationship between verb and any following constituent. They often stand alone but may be followed by other sentence constituents, provided these do not form part of the same clause. Conjunctive is un- or less marked morphologically, typically there being only tense markers (zero in the present and /a/ in the past). Disjunctive is marked by some combination of morpheme following the regular post-subject tense marker (most often /a/ or /la/, depending on tense and language) and tone. Typically, the contrast seems restricted to certain tenses, most often positive presents, or positive presents and pasts, and also most often does not occur in negatives, relativised verbs and verbs in certain other clause/sentence types. However, in some southern African languages (Tswana, Zulu) positive future and perfect, and some negatives, are also involved. It remains to be seen whether a wider selection of languages will show the same restrictions or not. From my 1970's fieldnotes, some N10 languages may have this kind of contrast, as my Matengo source, for example, said members of two pairs of past tenses did not differ in time reference but one member of each pair was "complete" while the other "required more words". Examples of conjunctive/post-verbal versus disjunctive/verb focus:

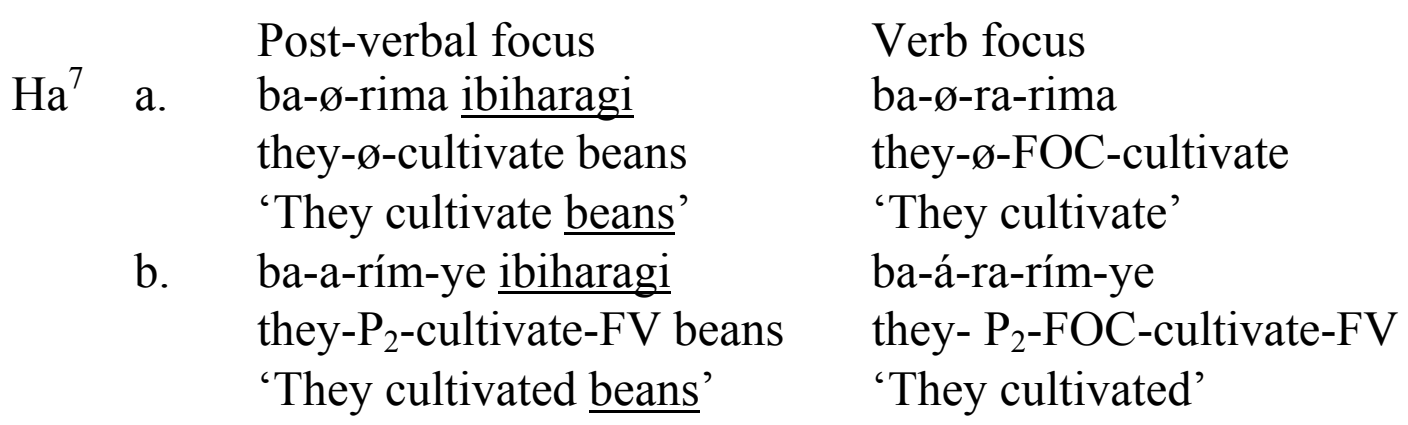

6 Conjunctive (post-verbal) and disjunctive (verb focus) both go under a variety of other names, for which see Güldemann (2003: 328).

7 These examples show structural and tonal differences (see Harjula 2004: 100). 


$\begin{array}{rll}\text { c. } & \begin{array}{l}\text { y-oo-tee-ye imbutó } \\ \text { he-POT-sow-FV seed } \\ \text { 'He would sow the seed' } \\ \text { bá-ø-bómba } \\ \text { 'They work...' }\end{array} & \begin{array}{l}\text { y-oo-tée-ye } \\ \text { he-POT-sow-FV } \\ \text { 'He would sow' } \\ \text { bá-ø-lá-bomba } \\ \text { 'They work' }\end{array}\end{array}$

In a few languages (E401(Ngurimi)-402-403-404-43-44, M54 (Lamba), and M60) la/ra occurs in what translates as a progressive or general present. Thus:

$\begin{array}{lll}\text { Ngurimi } & \text { tu-ra-gura } & \text { 'We buy, are buying' } \\ \text { Lamba } & \text { tu-la-cita } & \text { 'We do' }\end{array}$

Comparing the Lamba 'present' with the disjunctive in nearby Tonga (M64) (also Bemba), Güldemann (1996: 236) proposes a plausible connection. He suggests Lamba once also had a disjunctive (marked by la) versus conjunctive (zero marking) contrast but neutralized it in favor of the marked form, which thereby became the general present form. This explanation of Güldemann's would also provide a link from $r a$ elsewhere in Lacustrine languages to this E40 (e.g. Ngurimi) 'present'. That is, as with the Zone M languages, some Lacustrine languages have focal $r a$ (D60, e.g. Ha), the original meaning, and others have progressive/present ra (E40, e.g Ngurimi), the derived meaning.

\section{Three-way contrast: neutral versus verb versus post-verbal focus}

Odden (1996: 63-5) recognizes three focus types in Matumbi: neutral, verb, and post-verb ("noun") focus. Noun focus requires a non-verb to be the pragmatic focus of the clause and to appear in the immediately post-verbal position. Verb focus puts contrastive focus on the verb. Neutral forms do not assert that any element of the clause is focused. Unlike in nearby Mwera (Harries 1950: 92-9) where one marker $(k u)$ marks focus, several markers operate in Matumbi: ${ }^{8}$

a. Neutral focus: ni-ká-ba ka-ni-telek-á

I-ka-be ka-I-cook

'I am cooking.'

b. Noun focus: ni-ø-kata áanjú

I-ø-cut firewood

'I am cutting firewood (not something else).'

8 The role of $k a$ in these Matumbi examples is not clear. 
c. Verb focus: e-endá-teleká he-FOC-cook

'He is cooking (not talking).'

Wald (1997: 65) suggests Shambaa has a three way contrast, where zero indicates post-verbal focus, /a/ is neutral, allowing the verb to be within the maximal focus of the clause, and /ta/ has the verb as the maximal focus of the clause. Thus Shambaa:

$$
\begin{aligned}
& \text { ni-ø-dika manga } \\
& \text { n-a-dika (manga) } \\
& \text { ni-ta-dika (manga) }
\end{aligned}
$$

\author{
'I cook/ am cooking cassava' \\ 'I am cooking (cassava)' \\ 'I am cooking (cassava)'
}

He suggests Swahili once had a similar system, with $\varnothing, a$, and na corresponding to $\varnothing, a$, and $t a$, respectively. Shambaa and Swahili being related to the North East Coast Bantu languages (E70, G10, G20, G30, G40), these probably all once had the same system, if Wald is correct.

\section{Verb-initial ni-: verb focus, progressive (and present?)}

Some northeast languages have a verb-initial ni-, whose main function is often stated as assertion: E42-43-401, E46, E50 (not E56), E60. ${ }^{9}$ Although differences naturally exist between groups of languages and between individual languages, the similarities between E40 (e.g. Gusii, Kuria), E50 (e.g Gikuyu), and E60 (e.g. Vunjo) are striking. The various grammars and articles, mostly written in complete or almost complete ignorance of the others and at different points in the twentieth century, make very similar statements. The presence of $n i$ is said to represent greater certainty on the part of the speaker about the validity of what is being said, while the absence of $n i$ indicates less certainty. Typically it appears in positive statements and yes-no questions but not in relatives, negatives, or most WH-questions. When the possibility of assertion or certainty is not present, there is no contrast between the presence and absence of $n i .{ }^{10}$ Dalgish (1979: 5763) presents a number of arguments in favor of the proposition that the Chaga (E62) $n i$ itself derives from the copula, and in constructions originally involving copular $n i$ and a cleft construction ("It is that X, it is the case that X"), a

9 A set of languages in western Tanzania (F21, F22, F24, F31, F32) also have initial $n$-. It translates variously as relative, conditional, and "if/when". The connection between this and the $n i$ - of this section needs more examination.

10 Hyman has pointed out to me that while there is no assertion contrast in backgrounded clauses, there is a possibility of some focus marking: thus 'the woman who saw THE MAN' contrasts the referent, not the contents of the clause. 
proposition taken for granted by most of the other authors (Barlow 1960, Bennett 1969, Cammenga 2002, 2004, Moshi 1988, Nurse \& Philippson 1977, Whiteley 1960, Whiteley \& Muli 1962). ${ }^{11}$ The examples are from one or other of these authors (Dalgish 1979, Barlow 1960, Cammenga 2004, Dalgish, respectively).
a. Vunjo i. ni wasi $\underline{n}$-ulewaawa mdu
is clear FOC-you+killed person
'It is (abundantly) clear you killed someone', but
ii. ni wasi ulewaawa mdu
'It is (less) clear you killed someone'
b. Gikuyu i. nI-maathiire
'They went' ('It is a fact they went', verb focus)
ii. maathiire iyo
'They went two days ago' (post-verbal focus)
c. Kuria i. /ne-ßa-a-soma/ [mbaasóma]
'Indeed they have read'
ii. / / $\quad$ a-a-soma/ [ $\beta$ aasomă]
'They have read'
d. Vunjo ngileona kyelya kilya ulekora
I.saw that food you.cooked
'I saw the food which you cooked.'

The last example contains a restrictive relative clause. Since such clauses lack the possibility of an assertion contrast, there is no contrast between initial ni and zero (*n-ulekora is impossible here). At first sight the role of this ni- differs from what is presented for the languages in sections 5 and 6 . There are obvious differences, such as the absence here of the disjunctive: conjunctive contrast and the fact that ni co-occurs with most tenses/aspects, while disjunctive markers are typically restricted to a few tenses/aspects. But the general difference may be less than appears, because the analyses summarized in sections 5 and 6 are recent work, while most of the thinking about the ni-languages is older, preceding Dik's (1997 (1989)) work, and often contained in grammars whose main interest was not focus. Muriungi and Abels' (2005) analysis of Tharaka may lead to a change of thinking about the role of ni. Ni in Tharaka (E54, akin to Gikuyu E51) clearly marks focus. While it does not occur with negatives or (most?) relatives, it does occur with most positive indicative tenses and aspects, and it also occurs on preverbal focused object (and subject) nouns, and with preverbal WH-words in some circumstances. A smaller subset of northeastern

11 See also McWhorter (1992). 
languages (E102, E12-13-14-21-22-23-24) ${ }^{12}$ use the same morphology to express the difference between progressive (ni-) and non-progressive present (pre-stem zero) aspect. Thus:

\section{General present}

(9) Bwisi tu-ku-ghenda 'We go, will go'

(10) Tooro tu-ø-gúra 'We buy'

\section{Progressive}

n-tu-ø-ghenda 'We are going'

ni-tu-ø-gúra 'We are buying'

Güldemann (2003) discusses the connection between focal pre-verbal ni- and this progressive ni-. As Dalgish, he presents arguments connecting copula ni to assertive $n i$ and then linking assertive to progressive $n i$, and necessarily in that grammaticalisation direction: copula became focus marker became progressive marker - following Hyman and Watters (1984), he sees progressive as a category with inherent focus. It is not clear whether there are languages in this subset where progressive has moved on to general present.

\section{Recycling: verb focus to progressive to general present to non-past}

The focal strategies in sections 5 and 7 tend in the same direction, as older focus systems disintegrated. Güldemann (2003) establishes a connection between verb focus and progressives, and a specific direction: verb focus may become progressive. Those concerned with grammaticalization paths (Bybee et al (1994), Heine \& Kuteva (2002)) point out that progressives may broaden and become general presents, thus: verb focus $>$ progressive $>$ present. Progressives and presents are often extended to future reference, so they would cover nonpast, thus: verb focus $>$ progressive $>$ present $>$ non-past (or just future). Progressives becoming presents is not limited to progressives which derive from focus forms. ${ }^{13}$ Across Niger-Congo and Bantu, for example, the commonest form of progressive is based on a structure which is or was of the shape be+locative+infinitive $(l i-m u-k u)$. Over time this reduces to a CV shape, most often $k u$ or $k o$, and it is a safe bet that most general presents of that shape today originated as progressives. Bantu examples:

12 It is unclear how to interpret the ni in E403 ni-tu-ku-gura 'We buy, we are buying': focus or progressive? It appears to be the only form in the language with $n i$, which argues for progressive status. But the fact that there is no contrast with a ni-less form, and that it is used in the E40 area, which is the ni-focus area, argue for its focal status. E56, spoken in NE Tanzania, adjacent to G23, has undergone two changes. It has replaced E50 ni- by na, borrowed from G23, and this only occurs in the present, similar to E12-13-14-21-22-2324. See Nurse (2000).

13 Note also Swahili na, possibly once focus, now progressive for many speakers, and general present for others (Wald 1997). 

(11) a. Holoholo w-i-mú-ku-keba
b. Gogo ni-ku-gulá
c. Hungu tu-ku-sumba

\author{
'She is searching' (PROG) \\ 'I buy' (general present) \\ 'We will buy' (FUT)
}

Where Holoholo shows progressive aspect and an almost full (l)i-mu-ku shape, Gogo and Hungu show reduced shapes (*li-mu-ku $>k u$ ) and shifted meanings.

\section{$9 \quad$ Focus and tone}

Hitherto the emphasis has been on the morphology of focus and little coherent has been said of the role of tone in focus. Hyman (1999: 166) is the most detailed statement on this. His general conclusion can be summarized thus: "In some cases we have seen, focus has been morphologized as $[+\mathrm{F}]^{14}$...In no case, however, have we seen what can be called a "direct mapping" from focus to tone. That is, I am unaware of a "pure" example where semantic focus (and only semantic focus) unambiguously conditions a [ + focus] tonal effect, or where the absence of semantic focus (and only its absence) conditions a [-focus] tonal effect'. In each case the grammar mediates between semantic focus and tone." So, while tone certainly plays a role in Bantu focus marking, the "relationship is not direct."

The role of tone can be seen in the examples in (4), although not clearly. While the post-verbal and verb focus forms in the first Ha row have identical surface tones, underlyingly they behave differently (Harjula 2004: 100). In fact, all Ha positive forms with a focus contrast are tonally contrastive, but only some (present, the two pasts) are also morphologically distinct, while others (consecutive, potential) are morphologically identical (ibid). No Ha negative or relativized verb form is focally contrastive. In Haya, quite closely related to Ha, only one past today retains a tonal and morphological contrast (see (14)).

Creissels' (1996) study of Tswana (S31) shows only the present positive as tonally and morphologically distinct, and in S40 languages such as Zulu and Swati both the present positive and the anterior positive are morphologically and tonally distinct. Creissels (ibid) shows that other forms (present negative, anterior negative, future positive) in S30 and S40 languages also have the focal contrast but it is only tonal. No focal contrast of any kind occurs in other tenses/aspects, positive or negative, nor in any relativized verb.

The Haya (E22) situation is even more curious. Section 7 and (10) present cases where general presents (unfocussed) have become present progressives (focused). No mention was made there of tone because seemingly Haya tu-ø-

14 [+focus] stands for the syntactic feature, $[+F]$ for its morphologized analogue. 
gúra 'We buy' and ni-tu-ø-gúra 'We are buying (PROG)' are tonally identical. But, as the Tswana present, they do in fact differ in their tonal behaviour. Using a different verb (-kóm- 'tie' and the name Káto in the examples below), Hyman (1999) shows that certain forms in Haya undergo "tonal reduction". That is, if anything follows the verb in the same clause, the underlying $\mathrm{H}$ of the verb (and in fact other H's also) deletes: so ba-ø-kóma 'They tie (disjunctive)' but ba- $\varnothing-$ koma káto 'They tie Kato (conjunctive)'. Tonal reduction does not occur in the progressive: ni-ba-ø-kóma 'They are tying' but ni-ba-ø-kóma káto 'They are not tying Kato', nor in any negatives: ti-bá-ø-koma 'They don't tie', ti-bá-ø-koma káto 'They don't tie K', ti-ba-li-ku-kôma 'They aren't tying' and ti-bá-li-kukóma káto 'They're not tying K'.

So far, tonal behaviour supports the morphologically based assumption that the Haya general present and the progressive differ. But all Haya TAM forms divide into two ${ }^{15}$ : those that behave as the general present by undergoing tonal reduction, and those that behave as the progressive and do not:

(12) Tonal reduction (adapted from Hyman 1999: 161):

$\begin{array}{lll}\text { General present } & \begin{array}{l}\text { 'They tie', etc } \\ \text { ba-ø-kóma }\end{array} & \begin{array}{l}\text { 'They tie Kato', etc } \\ \text { ba-ø-koma káto }\end{array} \\ \mathrm{P}_{1} & \text { bá-kôma } & \text { ba-a-koma káto } \\ \mathrm{P}_{2} & \text { ba-øomíle } & \text { ba-ø-komile káto } \\ \text { Past habitual } & \text { ba-a-kóm-aga } & \text { ba-a-kom-aga káto } \\ \mathrm{F}_{1} & \text { ba-laa-kôma } & \text { ba-laa-koma káto } \\ \mathrm{F}_{2} & \text { ba-li-kóma } & \text { ba-li-koma káto }\end{array}$

(13) No tonal reduction (adapted from Hyman 1999: 162):

'They are tying', etc 'They are tying Kato', etc

$\begin{array}{lll}\text { Progressive } & \text { ni-ba-ø-kóma } & \text { ba-ø-komá káto } \\ \text { Anterior } & \text { bá-á-kóm-ile } & \text { bá-á-kóm-ile káto } \\ \text { Experiental } & \text { ba-lá-kom-íle } & \text { ba-lá-kom-íle káto } \\ \text { Persistive } & \text { ba-kyáá-kôma } & \text { ba-kyáá-kóm-a káto } \\ \text { Subjunctive } & \text { ba-ø-kóm-e } & \text { ba-ø-kóm-e káto } \\ \text { Imperative } & \text { kóm-a } & \text { kom-á káto } \\ \mathrm{P}_{3} \text {, etc } & \text { bá-ka-kôma } & \text { bá-ka-kóm-a káto }\end{array}$

Of the forms without tonal reduction Hyman says: “...such TAM's have an intrinsic morphosyntactic focus $[+\mathrm{F}]$, which derives from their marked semantic status... so negation is the marked polarity, subjunctive and imperative are

15 Hyman (p.c.) says similar tonal marking of focus also obtains in Ganda. 
marked moods, progressive and persistive are marked aspects" (also perfect and experiental).

This Haya data, and to a lesser extent that from Ha and Tswana, raises interesting questions, such as:

- in the Haya data, assuming tonal reduction fails to take place in categories which are intrinsically focused, it is easy enough to accept negatives, subjunctives, and imperatives are marked compared with positives, indicatives, or statements, but why should positive progressives, anteriors, experientals, persistives, and $\mathrm{P}_{3}$ have intrinsic focus, whereas positive perfective (except $\mathrm{P}_{3}$ ), and habitual aspects apparently have no marked semantic status or intrinsic morphosyntactic focus. The perfective and habitual forms in Haya have disjunctive and conjunctive forms, the others do not. In Ha and Tswana, only certain forms have focal contrast: why those forms and why are they not the same categories as those in (12) in Haya? In what sense are all the indicative members of (13) intrinsically focused?

- since most members of (13) are marked or more marked morphologically than those in (12), why do they also need tonal marking? Similarly in Ha and Tswana: why are some forms only marked tonally, while others are also morphologically distinct? Were such forms once marked tonally and morphologically ("linguistic redundancy"?) or did one kind of marking take over as the other faded?

- how does this systemic markedness correspond to the discoursepragmatic notion of focus?

- which other languages behave like this? It would be desirable to examine a selection of other languages to see how far this behaviour extends.

\section{Other strategies}

The content of sections 5 and 7 (and 4) is arbitrary by including only languages employing particular morphological strategies. This was done because I wanted to concentrate on strategies which are fairly widespread or for which I had data. Languages for which "focus" is mentioned but which represent it in some other way are: Grassfields (Watters (2003: 253-4) implies that only Aghem expresses it morphologically), D41 (Güldemann 2003), ?D42 (Mutaka 1994), E74a (Philippson \& Montlahuc 2003), G42 (Wald 1997), H10 (Hadermann 1996) ${ }^{16}$, H41 (Ndolo 1972), H42 (Takizala 1972), K30 (Güldemann 2003), ?K41, N10

16 De Clercq (1912) hints at the possibility of a disjunctive: conjunctive contrast in H16c when he says that the present is negated in two ways: by sidi when the verb stands alone (tu-sidi-kuend-a ko 'We are not going') but by si when material follows (tu-si-ku-enda ku buala $k o$ 'We are not going to the village'). 
(Ngonyani 2001, 2003), P20 (Harries 1950), and P30 (Kisseberth 2003, Schadeberg \& Mucanheia 2000), because the data is unclear or does not fit well into the larger blocks. Two strategies little investigated here are the preposing of infinitives (see Kongo example in (2)) and reduplication. ${ }^{17}$

\section{The "non-past tense-marker" /-a-/, a recycled focus marker?}

Nurse (in progress) studies tense and aspect across Bantu. 84\% of the languages in his database $\mathrm{e}^{18}$ have a pre-stem marker /a/, making it the commonest morpheme in that position in Bantu. $78 \%$ have /a/ with past reference and $27 \%$ with non-past reference: mostly present, some present and future, or, less often, just future. Some languages have /a/'s with past and non-past reference. $27 \%$ with non-past reference is some 135 languages (see fn. 19), a considerable total.

Historically, /a/ 'past' is not hard to explain because it can be reconstructed for Proto-Bantu ${ }^{19}$, but where does non-past /a/ come from? It is harder to explain than past /a/, because Proto-Bantu probably had a zero vast $\operatorname{present}^{20}$ (as *tu- $\varnothing$-lima 'We cultivate') and a locative-based progressive present (*tu-ø-li ku-lima 'we are cultivating' < 'we are at cultivating'). As there is no obvious role for a non-past /a/ in such a system, it is unlikely to have been the source of today's non-past /a/'s. Several languages today have contrastive past /a/, that is, with different tone or length /a/ can represent different degrees of past, e.g. near versus remote. But no language contrasts non-past zero and nonpast /a/, because different degrees of present temporal reference are impossible.

There appear to be four possible sources for these non-past /a/. At first I considered the possibility that past /a/ had shifted semantically to give present /a/ but found no grammaticalisation path in the major sources (Bybee et al 1994, Heine \& Kuteva 2002) from past to present, nor was there any obvious route in the Bantu data. If a few languages had gone that route it might have been treatable as a freak but for $27 \%$ to have travelled along an unapproved route is

17 The sources mentioned describe a range of tonal, segmental/morphological, and syntactic strategies. Güldemann (2003) discusses some at length.

18 The "database languages" are 100 languages, one from each of Guthrie's eighty-five groups, plus an extra fifteen, roughly one more from each of his zones. This gives good geographical and typological coverage. Percentages are of these 100 languages. Since there are some 500 Bantu languages/varieties, multiplying any percentage by five will give a rough idea of the total of languages with that feature.

19 Claims about Proto-Bantu, and all other claims in this section are based on Nurse (in progress).

20 The "vast present", a term coined by my colleague John Hewson, "is used to speak of states and processes which hold at the present moment, but which began before the present moment and may well continue beyond it" (Comrie 1985: 37), such as "Farmers produce crops". 
unlikely. A shift from older perfect to current present is a familiar grammaticalization route but older Bantu /a/ is unlikely to have represented a perfect, even though a few languages have an /a/ perfect today. A second possibility is that a short past [a] following the consonant and glide of subject marker could lengthen and eventually become reinterpreted as independent long /a:/. While this is plausible, it is an unlikely source for the non-pasts for two reasons: one is that such a process would represent past not present time, and second, it would result in a long vowel, but most non-pasts have short vowels.

A third possible source would be an original morpheme of the shape [Ca], which would lose its consonant to produce [a]. The commonest pre-stem tenseaspect morphemes occurring today across Bantu and having consonant plus the vowel [a] are, with incidence of occurrence in Bantu in brackets after each: / ka/ (71\%), various meanings but never present or non-past; /na/ (40\%), various meanings but rarely present or non-past; /nga/ (29\%) 'concessive'; /ma/ (25\%) 'anterior, past'; /laa/ (17\%) 'future'; /la/ (5\%) 'disjunctive, present'. A very few other such morphemes occur, with an incidence under $5 \%$, and with only local distribution. It can be seen from this overview that with the exception of $/ \mathrm{la} /$, incidence of occurrence $5 \%$, none of these represents a present or non-past meaning and none occurs anywhere near often enough to provide a single possible Bantu-wide source for non-past /a/ $(27 \%){ }^{21}$ This eliminates the possibility of a single morpheme of the shape $\mathrm{CV}$ as the source for non-past /a/.

This leaves the fourth possibility, that this "non-past" /a/, despite its label, did not originate in any morpheme once carrying temporal or aspectual reference. This forces one to consider that it used to represent not tense but focus. For this the evidence would be:

a) the fact that over a quarter of Bantu languages have an /a/ associated with non-past time reference, but an /a/ with such temporal reference is not apparently reconstructible for $\mathrm{PB}$.

b) the fact that several languages today certainly have it marking not tense but verb (disjunctive) focus, so D60, E22, S20-30-40-50, and K21. In the S languages it is associated with present verb focus, in D60 and E22 22 with recent past (Harjula 2004: 100, Hyman 1999):

21 Could la/ra 'disjunctive, present' have once been more common and become /a/ by deleting the liquid? Yes, in principle, but such deletion is not otherwise attested in most languages with only /a/ today.

22 So Haya (E22) has at least traces of separate tonal (see $(12,13)$ and morphological focus. 
(14)

\begin{tabular}{|c|c|c|}
\hline \multirow{4}{*}{ a. Ha (D66) } & Non-verb focus & Verb-focus \\
\hline & y-a-teeye ibigóori & y-a-a-a-téeye \\
\hline & $3-\mathrm{P}_{1}$-sow maize & $3-\mathrm{P}_{1}$-FOC-sow \\
\hline & 'He sowed maize' & 'He sowed' \\
\hline \multirow{3}{*}{ b. Haya (E22) } & y-a-koma káto & y-á-á-mu-kôma \\
\hline & 3-P $-\mathrm{P}_{1}$-tie Kato & 3- $\mathrm{P}_{1}$-FOC-him-tie \\
\hline & 'He tied Kato' & 'He tied him' \\
\hline \multirow[t]{3}{*}{ c. Tsonga (S53) } & hi-ø-dya vuswa & hi-ø-ạ-dy-á \\
\hline & we-ø-eat porridge & we-ø-FOC-eat \\
\hline & 'We eat porridge' & 'We eat' \\
\hline \multirow[t]{3}{*}{ d. Lozi (K21) } & ni-ø-lek-á nama & lw-ø-a-ca \\
\hline & I-ø-buy meat & I-ø-FŌC-eat \\
\hline & 'I buy, am buying meat' & 'We are eating' \\
\hline
\end{tabular}

c) a less certain set of data, where non-focal forms have a short vowel and focal forms involve a long vowel, which might be interpreted as the short vowel plus $/ \mathrm{a} /{ }^{23}$ Such cases need more investigation. Examples;
a. Aghem
Non-verb focus
Verb-focus
o mo bo fíghâm
o má-a bó ghâmfo
$3 \mathrm{P}_{1}$ hit mat
'He hit the mat'
b. Shambaa
i. n-a-káánga nyama
'I fried meat'
'I'm cooking meat'
ii. n-a-dika nyama

The examples in $(14,15)$ suggest that this /a/ occurs and occurred as the second in a sequence of pre-stem markers, in the position Meeussen (1967: 109) calls "limitative". The fact that so many languages today have /a/ with (non-past or present) tense reference, and few have it representing focus should not disturb. If the grammaticalisation path suggested in section 8 is correct, then this present/non-past reference is the final step on the path, but the languages affected have had over four millennia to reach this point. While not all of today's non-past /a/ necessarily originate in this disjunctive /a/, there is a good chance that many do.

23 Hyphens dividing the long vowel are mine. I have taken the liberty of interpreting Aghem maa as mo+a. Hyman suggests that, alternatively, mo might be a reduced form of maa. Sources for Shambaa do not totally agree on the lengths of the various pre-stem $/ \mathrm{a} /$. 
Güldemann (2003) proposed a grammaticalisation path from focus marker to progressive marker to present, to which I added "to future". He said this with $\mathrm{ra} / \mathrm{la}$ in mind. I have expanded this to include cases of /a/, which has a wide distribution than $r a / l a$, and to push it back possibly to PB.

\section{Conclusions}

This survey suggests that (1) constituent focus exists widely (at least twelve of Guthrie's fifteen Zones) in contemporary Narrow Bantu, and also in at least Grassfields Bantu, (2) verb (disjunctive) focus is the marked category, postverbal focus the unmarked (zero) category, (3) inflectional morphology and tonal behaviour play a central role in this marking, which is not surprising, given the agglutinating and tonal nature of Bantu and (4) this system probably goes back to Proto-Bantu in some form, because it is unlikely that so many languages would have innovated morphological focus of this type independently. Section 11 suggests that today's "non-past /a/" was once a central part of a focus system, because it occurs today in so many languages. Possibly /la/, present in far fewer languages, and maybe $/ \mathrm{na}^{25}$, earlier general role unclear, were also part of the focus system. Both /a/ and /la/ are predominantly associated with present time disjunctive focus reference: it is unclear which was associated with past focus reference, and it is possible, although unprovable, that /a/ and /la/ are related, via deletion of [1].

Where the focus system was maintained, new marking was innovated areally, e.g. pre-verbal $n i$, as in section $7 .{ }^{26}$ Where the system leaked, /a/ and /la/ were used in other ways, in the general direction suggested in section 8: verb focus $>$ progressive $>$ present/future/non-past.

25 Comparative evidence shows na associated with verbs as far back as PB but its status is uncertain. For Swahili Wald (1997) analyzes it as focus/progressive.

26 G. Philippson has suggested pre-verbal ni might be of Cushitic origin. The area where it occurs is known to have had an earlier Cushitic substratum. On the other hand, forms (-li, ni) of copula 'be' play a focus role in non-Bantu Niger-Congo languages and also crosslinguistically. 


\section{References}

Barlow, A.R. (1960) Studies in Kikuyu Grammar and Idiom. Edinburgh: Blackwood.

Bennett, P.R. (1969) A Comparative study of four Thagicu verbal systems. London: SOAS. $\mathrm{PhD}$ thesis.

Bybee, J.L., Perkins, R.D., \& W. Pagliuca. (1994) The Evolution of Grammar, Tense, Aspect and Modality in the Languages of the World. Chicago: University of Chicago Press.

Cammenga, J. (2002) Phonology and Morphology of Ekegusii, a Bantu Language of Kenya. Cologne: Rüdiger Köppe Verlag.

---- (2004) Igikuria Phonology and Morphology - A Bantu Language of South-West Kenya and North-West Tanzania. Cologne: Rüdiger Köppe Verlag.

Comrie, B. (1985). Tense. Cambridge: CUP.

Creissels, D. (1996) Disjunctive and conjunctive verb forms in Setswana. SAJAL 16, 4: 10915.

Dalgish, G.M. (1979) Morphophonemics of the OluTsootso dialect of OluLuyia: Issues and implications. Urbana: University of Illinois. $\mathrm{PhD}$ thesis.

de Blois, K.F. (1970) The augment in the Bantu languages. Africana Linguistica 4: 85-165.

De Clercq, L. (1912) Grammaire du Kiyombe. Brussels: Goemare, Imprimeur du Roi.

Dik, S.C. [ed. by Hengeveld, K.) (1997) The Theory of Functional Grammar. Part 1: The Structure of the Clause. Berlin/New York: Mouton de Gruyter. (Originally 1989)

Dimmendaal, G. (1995) Metatony in Benue-Congo. In: E.N. Emenanjo \& O.-M. Ndimele (eds.), 30-8.

Emenanjo, E.N. \& O.-M. Ndimele (eds.) (1995) Issues in African Languages and Linguistics: Essays in Honour of Kay Williamson. Aba: National Institute for Nigerian Languages.

Guarisma, G. (2003) Kpa? (A53). In: Nurse \& Philippson (eds.), The Bantu Languages. London: Curzon Press. 307-34.

Güldemann, T. (1996) Verbalmorphologie und Nebenprädikation im Bantu. Bochum: Universitätsverlag Dr. N. Brockmeyer.

---- (2003) Present progressive vis-a-vis predication focus in Bantu, a verbal category between semantics and pragmatics. Studies in Language 27,2: 323-60.

Hadermann, P. (1996) Les marques -yo- et -to- dans quelques langues bantoues de zone C. Afrikanistische Arbeitspapiere 38: 163-80.

Harjula, L. (2004) Kiha Grammar. Helsinki: University of Helsinki, Institute for Asian and African Studies. PhD thesis.

Harries, L. (1950) A Grammar of Mwera. Johannesburg: Witwatersrand University.

Heine, B. \& T. Kuteva. (2002) World Lexicon of Grammaticalization. Cambridge: CUP. 
Hyman, L.M. (1999) The interaction between focus and tone in Bantu. In: G. Rebuschi \& L.

Tuller (eds.). The Grammar of Focus. Amsterdam: John Benjamins, 151-77.

---- 2003. Basaa (A43). In: D. Nurse \& G. Philippson (eds.), 257-82.

Hyman, L.M. \& F.X. Katamba. (1993) The augment in Luganda: syntax or pragmatics? In: S. Mchombo (ed.) Theoretical Aspects of Bantu Grammar. Stanford: CSLI, 209-56.

Hyman, L.M. \& J.R. Watters. (1984) Auxiliary focus. Studies in African Linguistics 15: 23373.

Kisseberth, C.W. (2003) Makhuwa (P30). In Nurse \& Philippson (eds), The Bantu Languages. London: Curzon Press. 546-65.

Maho, J. (2003). A Classification of the Bantu Languages. In: D. Nurse and G. Philippson (eds.). The Bantu Languages. London: Curzon Press. 630-51.

McWhorter, J.H. (1992). Ni and the copula system in Swahili: a diachronic approach.

Diachronica 9,1: 15-46.

Meeussen, A.E. (1967). Bantu grammatical reconstructions. Africana Linguistica 3: 80-121.

Moshi, L. (1988) A functional typology of ni in Kivunjo (Chaga). Studies in the Linguistic Sciences 18: 105-34.

Muriungi, P. \& K. Abels (2005) The focus particle in Kitharaka. Paper presented at the Conference on Focus in African Languages, ZAS, Berlin.

Mutaka, N.M. (1994) The Lexical Tonology of Kinande. Munich: Lincom Europa.

Ndolo, P. (1972) Essai sur la tonalité et la flexion verbale du Gimbala. Tervuren: MRAC.

Ngonyani, D. (2001) A descriptive grammar of Kindendeuli. East Lansing: Michigan

State University. Ms.

---- (2003) A Grammar of Chingoni. Munich: Lincom Europa.

Nurse, D. (2000) Inheritance, Contact, and Change in Two East African Languages. Cologne:

Rüdiger Köppe Verlag.

---- (in progress) Tense and Aspect in Bantu.

Nurse, D. \& G. Philippson (1977) Tone in Old Moshi. Studies in African Linguistics 8,1: 4980 .

Odden, D. (1996) The Phonology and Morphology of Kimatuumbi. Oxford: OUP.

Philippson, G. \& M.L. Montlahuc. (2003) Kilimanjaro Bantu (E60 and E74). In: Nurse \& Philippson (eds), The Bantu Languages. London: Curzon Press. 475-500.

Schadeberg, T.C. (1995) Object diagnostics. In: Emenanjo \& Ndimele (eds.), 173-80.

Schadeberg, T.C. \& F.U. Mucanheia. (2000) EKoti: The Maka or Swahili language of Angoche. Cologne: Rüdiger Köppe Verlag.

Takizala, A. (1972) Focus and relativization: the case of Kihung'an. Studies in African Linguistics 3,2: 259-84. 
Wald, B. (1997) The 0 tense marker in the decline of the Swahili auxiliary focus system. Afrikanistische Arbeitspapiere 51: 55-82.

Watters, J.R. (1979) Focus in Aghem. In: L. Hyman (ed.). Aghem Grammatical Structure. Los Angeles: University of Southern California. Southern California Publications in Linguistics 7, 137-98.

---- (2003) Grassfields Bantu. In: Nurse and Philippson (eds.), The Bantu Languages. London: Curzon Press. 225-56.

Whiteley, W.H. (1960) The Tense System of Gusii. Kampala: East African Institute of Social Research.

Whiteley, W.H., \& M.G. Muli. (1962) Practical Introduction to Kamba. London: OUP.

dnurse@mun.ca 